\section{RIMCIS \\ Social Sciences}

\section{Hipatia Press}

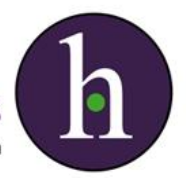

Instructions for authors, subscriptions and further details:

http://rimcis.hipatiapress.com

\title{
Discourse analysis on Nationalism debate reported in Indian print media during Feb-Mar 2016
}

Shovana Ray ${ }^{1}$, Jitendra Kumar Singh ${ }^{1}$

1) Defence Institute of Psychological Research, India

Date of publication: November $30^{\text {th }}, 2017$

Edition period: November 2017 - February 2018

To cite this article: Ray, S., \& Singh, J.K. (2017). Discourse analysis on Nationalism debate reported in Indian print media during Feb-Mar 2016. International and Multidisciplinary Journal of Social Sciences, 6(3), 251-280. doi: 10.17583/rimcis.2017.2899

To link this article: $\underline{\text { http://doi.org/10.17583/rimcis.2017.2899 }}$

\section{PLEASE SCROLL DOWN FOR ARTICLE}

The terms and conditions of use are related to the Open Journal System and to Creative Commons Attribution License (CC-BY). 


\title{
Discourse Analysis on Nationalism Debate Reported in Indian Print Media during Feb-Mar 2016
}

Shovana Ray

Defence Institute of Psychological

Research
Jitendra Kumar Singh

Defence Institute of Psychological

Research

\begin{abstract}
In the age of progressing information technology, media reporting has evolved in the selection, role portrayal, articulation of the news on the basis of presentation and comprehensibility. Both print and broadcast media have reformulated news reporting pattern considering the current global market, advertising and latent political agendas. Use of particular discourse not just influences mindset; its rhetorical presentation modulates perception on an explicit level. News as a discursive tool transforms the reader's perception on the topic. In the initial phase of 2016, Indian media extensively reported an incident at Jawaharlal Nehru University (JNU) New Delhi and its effect on the pro- and anti- national sentiments. The reporting was in the context of slogan shouting by a group of students, which was perceived to be anti-national. With due course of time, debates restructured the news into a nation-wide sensation involving various facets, such as, importance of nationalism and patriotism, credibility of the university education, involvement of students from different ideological and identity background (Dalit, Kashmiri Muslim, etc.). In this paper, broad categorisation is being made, namely as, JNU (the university, administration, faculty and its culture), the students (JNUSU president, ASFI members and AVBP members), the state (Judiciary, the ruling party and the opposition parties) and the others (media, celebrities, lawyers and citizens). The present study discusses the impact of news as discourse on the ideological position and activities of news characters (actors) as well as its contextual salience in the national politics.
\end{abstract}

Keywords: identity, news as discourse, nationalism, politics in higher education institutions 


\section{Análisis de Discurso del Debate del Nacionalismo Informado en los Medios Impresos de India durante Febrero y Marzo 2016}

Shovana Ray

Defence Institute of Psychological

Research
Jitendra Kumar Singh

Defence Institute of Psychological

Research

\section{Resumen}

En la era de una progresiva tecnología de la información, la elaboración de las noticias en los medios han evolucionado en la selección, la representación de roles, la articulación de las noticias sobre la base de la presentación y la comprensión. Tanto los medios impresos como los de radio han reformulado el patrón de informar sobre las noticias teniendo en cuenta el mercado global actual, la publicidad y las agendas políticas latentes. El uso de un discurso particular no solo influye en la mentalidad; su presentación retórica modula la percepción en un nivel explícito. Las noticias como herramienta discursiva transforman la percepción del lector sobre el tema. En la fase inicial de 2016, los medios indios informaron extensamente un incidente en la Universidad Jawaharlal Nehru (JNU) de Nueva Delhi y su efecto sobre los sentimientos pro y antinacionales. Las noticias se realizaron en el contexto de los gritos de un lema de un grupo de estudiantes, que se percibió como antinacional. Con el transcurso del tiempo, los debates reestructuraron las noticias en una sensación nacional que involucraba varias facetas, como la importancia del nacionalismo y el patriotismo, la credibilidad de la educación universitaria, la participación de estudiantes de diferentes orígenes ideológicos y de identidad (Dalit, cachemira musulmana, etc.). En este documento, se está haciendo una amplia categorización, como JNU (la universidad, administración, profesorado y su cultura), los y las estudiantes (presidente de JNUSU, miembros de ASFI y miembros de AVBP), el estado (poder judicial, el partido gobernante y la oposición) y los demás (medios de comunicación, celebridades, abogados y ciudadanos). El presente estudio analiza el impacto de las noticias como discurso sobre la posición ideológica y las actividades de los personajes de noticias (actores), así como su relevancia contextual en la política nacional.

Palabras clave: identidad, noticias como discurso, nacionalismo, políticas universitarias 
I

$\mathrm{n}$ the era of affluent broadcast \& social media, print media is acquiring an endangered status. As business survival, Print media is restructuring in formats more suitable to the needs of present generation readers, such as web news accessibility and mobile applications. With all possible forms, news text remains an important source of local and global source of information for the readers. Hence, News texts are common form of written discourse. Online news, being easily accessible on non subscription facilities, attracts readers equally as broadcast media. News texts, both on paper and websites are preserved as valuable archives and serve as primary data in social science researches. News is supposed to be value neutral and objective, hence maybe used as unbiased data. As a critique of this premise, news text reflects the business model based on customer based news production and the political model based on ideologies associated with the government and media houses (Chomsky \& Herman, 1988). News production is a continuous process, as the text is a representation of information collected from the diverse sources including specific group of informants and is further presented to a wider group of people. The biased-unbiased stand of news text may be detected by the syntax and semantics used in the headlines and subsequent news stories. Discourse, analysed on the line of Social constructionist approach focuses on the meaning production process, based on four assumptions, namely, 1) they are socially constructed; 2) inter-textually between socio-political and cultural aspects of historically constituted concepts; 3) multiplicity of meaning available for a single actor in a particular situation; 4) different meanings as multiple and overlapping resources influencing social actors.

Publishing of particular news is dependent on several factors termed as 'filters' by Chomsky \& Herman (1988). There are five filters, 1) media ownership; 2) advertising houses; 3) sources of news; 4) reader's response; 5) avoidance of communism. Breaching these filters, news text are designed to be value neutral, but language content carries the effect of filters on an ideological level (Mooney \& Betsy, 2015). Acceptance and popularity of any newspaper is based on the readers' trust on the particular media house, which is modulated by semantic unity (Van Dijk, 1983) and news values (Bell, 1991). Semantic unity of any text can be assessed by the consistency of news flow, i.e. whether the story is progressing according to the headline 
and lead or changes in the midway or end. News value is the newsworthiness (Mooney \& Betsy, 2015) of the story, i.e. the significance of the event and actors in the said socio-temporal domain. Other than these, the marketing strategies and age of media house also plays role in the selection of a newspaper. After the reader selects the newspaper, reading of the news story is dependent on the headline, picture, captions and the writer. The interplay of politics, power and ideologies influence the syntax and semantics of the text which creates a demonstrable discord in the discourse. The resultant impact created by the news reports are criticised with the objective of emphasising the use of politically driven discourse instead of comparatively neutral and value free text. In this paper, we have highlighted nature of publicity by the leading Indian media house while presenting 2016 JNU protest.

\section{The News}

On 9th February, 2016 a cultural event was proposed under the title 'Poetry Reading - 'The Country without A Post Office' to be organised at Sabarmati Dhaba, Jawaharlal Nehru University Delhi. With due written permission, arrangements were initiated. Later The University authorities cancelled the permission saying that organisers have not provided detailed information regarding the event. The posters implicated the programme to be an event showing solidarity with the demand of the Kashmiri people for their democratic right to self-determination (Appendix 6) and to criticize the 2013 hanging of Parliament Attack convict, Afzal Guru. Some of the assembled students shouted slogans, a few of which are alleged to have been antinational, leading to a scuffle between the ABVP and the Left organisations present there. ABVP student leader complained to the JNU authorities that the event had anti-national contents, which eventually led to police interruption in the campus followed by a detailed speech by JNU Students Union president Kanhaiya Kumar on 11 February 2016 (Kumar, 2016a). As a result, he was charged with sedition and criminal conspiracy, and subsequently arrested along with many of his associates. What followed thereafter was reported and recorded in the court and media extensively for a period roughly extending more than one month (Appendix 1). The post- 
event debate and discussion included more than one epicentre covering issues such as anti-national debate, freedom of expression, role of JNU, involvement of Dalit perspective and political ideologies governing the entire issue.

\section{Present Study}

In the present study, the event is being discussed in light of the above mentioned criteria because a comparative evaluation of media reporting illustrates the discourse elaborately leading to an ambiguous causeconsequence analysis (Wodak \& Meyer, 2001). Initially the news reporting portrayed JNU as the protagonist, but gradually several actors played vital role in the formation of news (Van Dijk, 1988a). Amidst the various news agencies, in the present study, reporting are selected from print media only, as broadcast media and social media requires analysis of additional stimuli other than just discourse. Discussions are shaped based on the two fold objectives of answering how the various actors are represented through the use of language, and to what extent media contributed in creating a neutral or biased stand of the actors and the overall event.

\section{Method}

An event followed by media unrest, judicial involvement, social debates and political interference marks certain level of impact on the readers. The 9/2/16 JNU event, as it has received variety of nomenclature from the media in its due course of progress, is being addressed in this study as 2016 JNU protests (n.d.). Forums like print media, news channels, social networking websites, personal blogs, political speeches, and public debates encompassed the present event during February 2016. In this study, only news reports from print media are analysed. The Times of India (TOI) was selected on the basis of its popularity and circulation (Audit Bureau of Circulation, 2016). It is the largest English daily newspaper in India as well as the sixth largest newspaper in terms of circulation with its head office at Delhi followed by The Hindu and Hindustan Times. Its online and App-based readership is also highest in India (Audit Bureau of Circulation, 2016). TOI's position in 
Indian media is not only because of its simple language, it also belongs to the biggest media conglomerate in the country, The Times Group (Bennet, Coleman and Co. Ltd.). The current owners of the conglomerate took over TOI in 1986, when the newspaper was in decline (Menon Malhan, 2013). Since then, the newspaper is running in a business model leading to its current success status (Kohli-Khandekar, 2010). TOI, alike its other counterpart media agencies, has been criticized for its corporate, neo-liberal capitalist bias (Chaudhuri, 2010), but in terms of aligning towards any particular political party, TOI is usually considered value neutral.

Although the $2016 \mathrm{JNU}$ protests ranged from February to October and is still under Judiciary, the highest media coverage was during February and March, approximately one month. Since TOI is published and circulated nation-wide, only the Delhi/NCR (National Capital Region) editions were enlisted for the study. News articles with content related to the protest, direct comment and criticism by public figures, administrative actions and judicial proceedings were collected from archive section of online portal of each newspaper. As a selection filter, headlines with phrases like, JNU/JNUSU/ABVP, name of students and leaders involved, nationalism, sedition, anti-national, slogan, Afzal, police, court, journalist, and lawyer were picked for further analysis.

Contemporary development of discourse analysis profoundly draws contribution of scholars like Van Dijk (1988a), Wodak (1989), and Fairclough (1992). Among the three, Van Dijk's (1988b) model calls for an overall analysis of the text, its structure and process of production based on power and ideology (Boyd-Barrett, 1994). Wodak's (1989) model specifies in the historical involvement in any discourse production and analysis, whereas, Fairclough (1992) puts emphasis more on the news comprehension from reader's point of view. In the present study, Van Dijk's (1988b) sociocognitive model is being used for the analysis, which claims that discourse is not only text but involves social components in its production and cognitive components during its conception. Apart from the syntax and grammar analysis of the headline, lead, physical structure of news reports and frequency of the news are considered for the analysis (Van Dijk, 1988b).

Amongst the variety of news articles published on the 2016 JNU protest, similar reports of Hyderabad Central University (HCU) and University of 
Delhi were present in the media. The present study consists of analysis of news headlines of articles (not editorials) associated with the 2016 JNU protest. Following the inclusion criteria, 30 news articles out of 310 were selected for further analysis (Appendix 3). The articles were front page top position placed, from each day of the month (10 February 2016 - 10 March 2016). The rationale behind conducting this study was to understand the portrayal of the event by a distinguished Indian media houses and its pattern following one month duration, post event.

\section{Analysis}

The 2016 JNU protest is not the first event of its kind held in higher education institutes of India (George, 2016a). Issues of nationalism, Dalit rights and campus ideologies are streaming continuously in institutes of national importance, such as, Hyderabad Central University, Jadavpur University, University of Delhi and Jawaharlal Nehru University (Roy Choudhary \& Grover, 2016) Although the flare of protest is instigated by students' wings of major political parties, participants associated with the cause add to the discourse along with their personal viewpoints. Nationalism in India, either Hindu or secular (Varshney, 1993) articulates wide range of contrasting meanings, especially with reference to the JNU discourses (Martelli \& Rahman, 2016). The issue of judicial killing raised on 9 February 2016 was portrayed as a threat to Indian democracy by the University opposition parties, political leaders and media. Transparency and justification of the speech was subjected to distortion and repeated manipulation (Garg, 2016), leading to a chaotic phase on national podium. National-anti national debate was an overall shield to cover wider issues like poverty and social inequality prevailing in the country. Followed by the event, different antagonistic adjectives were added to JNU and the students involved (Press Trust of India, 2016a; TNN, 2016b; Gohain, 2016a). In such situation, media plays an important role because readers' perception is modulated less by the actual fact, but more by the news, both on broadcast and print. 


\section{Macrostructure and Superstructure}

Macrostructures are crude derivative from a text formed on the basis of knowledge and beliefs. They may be inter-subjective; the most prominent information of a news article may vary on the basis of reader's cognition and expectation (Van Dijk, 1980a). Macrostructures are strategic presentation of a text which serves the purpose of storing information in memory, but also that such macrostructures represent the information that is best recalled, whereas microstructure or local meaning details are usually forgotten alter longer delays (Van Dijk \& Kintsch, 1983).

In case of $2016 \mathrm{JNU}$ protest, there were plural macrostructures based on multiple actors. Each of the 30 articles produced a semantic macrostructures based on the three-level coding (Appendix 4) forming six schematic superstructures of the entire event (Van Dijk, 1988b). The superstructures were clustered from the microstructures based on their eventual position in the event; as stated below:

(1) JNU's political position was presented as a rebellious institution exploiting the state facilities and producing anti-national ideology amongst students.

(2) Unprecedented judicial killing of Parliament attack convict Afzal Guru was questioned by the protesting students, followed by their arrest under sedition.

(3) Union ministers claimed JNUSU president's speech as 'anti-national' and anticipated it as threat to national integrity.

(4) The videos and discourse broadcasted by the media invoked an omnipresent nationalism debate in media and academia.

(5) Few MLAs and lawyers threatened and attacked JNUSU students and president.

(6) Students arrested under sedition charges were found not guilty by the court and the videos responsible for the whole debate was proved to be forged.

Frequency of the News: Although there are no specific rules regarding limits of news publications on a single issue (Press Council of India, 2010), such decisions rest on business interest of media houses. Times of India, 
being one of the most popular news agencies of India (Audit Bureau of Circulation, 2016) published 310 news articles directly related to 2016 JNU protest (Appendix 2) excluding the editorial section. Publications related to the event, lasted throughout the month in the mainstream news section. For the analysis, the total period of one month (10 February 2016 to 10 March 2016) was equally divided into three temporal stages, namely, initial, mid and residual. More articles were in the mid stage followed by the initial stage and the residual stage.

The pattern of coverage frequency escalated with the reporting of sedition and consequent involvement of political leaders. Recurrence of news related to the event was encouraged as a political debate between the majorities of political leaders. Within a week of the event, media circulated jargons like 'anti-national' as addressed by the union ministers marking a sudden rise of coverage frequency. Encompassing the one month period, on 18 February 2016, there were highest reporting. The initial period marked a state of 'panic' (Van Dijk, 1988a), as published in the TOI (Bhattacharya \& Shakil, 2016).

Considering the qualitative aspect of news appearance, TOI created widespread and more dramatic stand in the initial stage to create the readership on the issue. The mid stage created a wider space for discussing the 2016 JNU protest, incorporating political views, social response and judicial follow ups. The residual stage especially consisted of Editorials and graphical portrayal of the news actors. Heavy news reporting in the initial stage acted as way of commercialising the debate and creating a forum for collateral discussions of National interest. Along with newspapers, broadcast media also flared up protest and associated debates. As the 2016 JNU protest was followed by the Union Budget announcements, media houses had the option to control the defamation (Press Council of India, 2010) of University, student and political leaders supporting the debate (Chatterjee, 2016). The unrestrained flow of news reporting was not parallel to the other national events going on; it was politically influenced (Desai, 2016).

Position of the News: Overall macrostructure of the news juxtaposed with the physical position of news articles showed congruent findings. Initial article was a moderate sized lower left placed page 5 reporting under 'city' 
section. Ideological position of the article is reflected prominently by the headline: JNU pulls plug on event against 'judicial killing' (TNN, 2016a). With direct name of the university as agent, there is lack of neutrality maintained. Other than the headline, the lead covers all the actors, namely, the University, ABVP, Afzal Guru, students involved in protest.

One month coverage of 2016 JNU protest was consistently highlighted in TOI; throughout the period, widely the articles were positioned in page one $(\mathrm{N}=37)$ and page two $(\mathrm{N}=64)$ and their follow-ups in page three $(\mathrm{N}=10)$, page four $(\mathrm{N}=19)$, page five $(\mathrm{N}=9)$, page six $(\mathrm{N}=34)$, page seven $(\mathrm{N}=$ $16)$, page eight $(\mathrm{N}=29)$, page nine $(\mathrm{N}=8)$, and page ten $(\mathrm{N}=5)$. Being the highest circulated paper in the country, discourse produced by TOI plays role in shaping social cognition of the readers (Van Dijk, 1990). Prominent position of news articles attracts the reader and the grouping of actors in the report sustains readers' curiosity for further follow up. Other than this, readers' interest was directed towards the 2016 JNU protest and distracted from other contemporary issues of national importance.

\section{Microstructure}

Macrostructure observes the abstract, overall structure expressed at a concrete level of overall news presented as sentences whereas microstructure distinguish meaning and its expression in exterior structures, such as phrases, clause, and sentence forms (Van Dijk, 1980a). There are two levels of presence and absence of actors in the headline and news text based on their role and portrayal of role in the article (Van Leeuwen, 1996), known as Suppression and Backgrounding. Beside presence of the actors, suppression means the absence of actor in the entire text, whereas backgrounding is deemphasising of actor in the text. In case of multidimensional event like the 2016 JNU protest, there was a periodical involvement of the actors resulting in complete absence of actors of the final phase in the initial stage of the month. An actor is not essentially an individual character in the text but may be a collection of characters of similar role in the text (Van Leeuwen, 1996). There were five actors influencing the entire event being present, suppressed, back grounded and absent in the news texts; they are- JNU administration, JNUSU students involved in the protest, ABVP students 
opposing the event, Ministers involved in debate, Leaders of opposition partisan national politics (Appendix 5).

Lexical style of the news: Text used in the news articles consists of grammatical accentuation of an event or actor under consideration. Choice of words to describe the actor and action emphasises their role in the text (Van Dijk, 1980a). Although lexical pattern of the headlines act as primary eye catcher for the reader to read further, text lexicons strengthens reader's affiliation with the actors. In case of all the headlines, $2016 \mathrm{JNU}$ protest was titled by TOI as Afzal event (TOI, 2016a) and JNU turmoil (TNN, 2016c). Beside the event, 'JNU' is used synonymously with university as a whole, institutional ideology and administration. Framing of sentences as active or passive voice is important. Actors presented with active voice are emphasised as the doer whereas if presented with passive voice become redundant in action (Van Dijk, 1988a). In the initial news headlines JNU is presented with active voice as of the subject/ actor in the headlines whereas simply as the object/ target in the proceeding texts. For all the front page headlines throughout the month of Feb-March, JNUSU students involved in the protest and Ministers involved in debate were presented with active voice, as the doer or subjects confronting each other. ABVP students opposing the event were not presented in the headlines as subjects but only the texts. One of the major concerns associated with presentation of a news article is the use of individual names and identities (Van Dijk, 1988b). Repeated use of names of individuals in the news may lead to defamation, particularly when the person is under judicial trial and not convicted yet. For 2016 JNU protest, name of students associated with the event were dilapidated with recurrent use in headlines and news text (Gohain, 2016c; Chakravatry, 2016; Garg \& Shakil, 2016; TNN, 2016i; Gohain, 2016d; Bhagwat, 2016; TNN, 2016j; TNN, 2016k). Instead of unwarranted repetition of names, anonymity could have been maintained.

Rhetoric pattern of the news: Rhetoric expresses formulation and context of the discourse (Van Dijk, 1980b) dealing with persuasive speaking or writing pattern. Rhetorical structures associated with assertive speech presented in the news text enhance the beliefs of the readers assigned to the 
asserted suggestion of the text. Persuading the reader may be subtle change of opinions or attitudes only (Condor, Tileaga, \& Billig, 2013).

In the one month debate political rhetoric is evident in speech of JNUSU students involved in the protest, Ministers involved in the debate and other political leaders from the opposition parties. Groundwork of the 2016 JNU protest was rooted in students' unrest related to the way Government handled student's movements in other universities, especially Hyderabad Central University (HCU). In all the text published, statements by JNUSU students reflect significant power led suppression by the Government, as cited below (TOI, 2016):

Even as protests continued to rage over an event held at JNU to mark the Afzal Guru hanging, Delhi Police's move to slap sedition charges on a group of unknown persons evoked a strong reaction on Thursday. Student groups called the police action "misuse of power to settle political differences" and likened it to the events leading to the death of University of Hyderabad student Rohith Vemula. Shehla Rashid, JNUSU vice-president, said: This is going overboard and a repeat of the HCU incident. On this campus, everything happens through a dialogue process. Involving the police and state machinery is nothing but misuse of power.

Use of particular phrases like, 'slap sedition', 'misuse of power' and 'going overboard' indicates the perception regarding political power embossed by government. This power rhetoric is signifying interference of police (government) in University campus issues. As mentioned earlier, Ministers involved in the debate created the political rhetoric of anti-nationalism surrounding the event, as cited below (Jha, 2016):

On a day Union home minister instructed Delhi Police not to spare anyone indulging in anti-India activities, cops arrested JNU students' union president Kanhaiya Kumar on sedition charges over a pro-Afzal Guru event held on campus earlier this week, prompting fierce protests from students and teachers in the university. There was heavy police presence at JNU as students clashed with cops, who went on to search hostels looking for "anti-nationals". 
As a national leader, the rhetorical use of words spoken and published influence the audience perception of the event. The repeated use of phrases like 'anti-national' and 'not spare' create an environment of hostile rhetoric (Condor, 2000). Other than the national leaders, political leaders of different parties consistently commented on the issue. The rhetorical comparison drawn between the two actors, JNUSU students involved in the protest and Ministers involved in debate displays power abuse (Wodak \& Meyer, 2009).

\section{Discussion}

The first query arising out in this study was the importance laid off to the 2016 JNU protest by Indian media houses. Over a stretch of one month, everyday at least one news article was published over the issue in TOI. An event of politically charged nature was not novel to the history of JNU; students are involved in active political discussions and encouraged to develop keen analytical interest in issues of national interest (Martelli, 2016). Contemporary JNUSU consists of both right-winged parties and leftwinged parties, but primarily feminism and Dalit centred communist ideologies are prevalent in everyday discourses (Martelli \& Rahman, 2016). For a premier educational institutes envisioned to train students and scholars in analytical political thinking, JNU suffices a dynamic curriculum and liberal campus structure. In case of such an active university campus, 2016 JNU protest was unduly overrated by media leading to further national-level debate. Grass root reason behind the protest was a non-violent event of poetry recitation and photo exhibition, organised by ten students inside the campus to express their solidarity with the Kashmiri people (Appendix 6the poster of the event).

Discourse plays important role in the expression, functioning and reproduction of cognition and resultant ideologies (Van Dijk, 1998), due to the pattern of language used. It governs the attainment, argumentation, conflict of interest, and other processes in the formation and amendment of ideologies. But ideologies cannot be reduced to discourse entirely as it is dynamically modified with other social practices (Van Dijk, 1998). As discourse, talks and texts acquire the power of influencing the cognition of a reader. In case of 2016 JNU protest, there was underlying ideological 


\section{Ray \& Singh - Discourse Analysis on Nationalism in India}

conflicts subtly guiding the entire national debate. The question was not of the nature of nationalism prevailing among JNUSU students involved in the protest; rather, it was of the ideologies related to the schemata (Billig, 1991). Ideological burst up of ABVP on 'anti-nationalism', 'disrespect to martyrs', and 'integrity of India' were not at all counter-reflections of the event agenda as rendered in the event poster (Appendix 6). Restoration of people's right in Kashmir, as a national issue already debated on International platform, was the context (Van Dijk, 1998) behind the event. News reporting were rarely addressing the context, however, the TOI editorial reports $(\mathrm{N}=$ 48) were inclined to caress multiple views from different social thinkers, scholars and authors. This paper did not cover further analysis of editorials as those were subjective reflections in the debate, whereas news reporting was more factual in nature.

\section{Actors and Their Role}

News is a medium of communication between the news actors and readers via an agency (media) maintaining facts and objectivity (Pajunen, 2008). News actors are supposed to be presented in a value neutral position in case of debates and discussions, but semantic and lexical choice of the news reporting add qualifier to the news actors. A news actor is not necessarily an individual person, it may be a group of persons associated with unanimous on an idea. Multiple news actors were associated with the 2016 JNU protest, but in this paper five have been identified who were directly involved in the debate. The five news actors in the entire event were JNU administration, JNUSU students involved in the protest, ABVP students opposing the event, Ministers involved in debate, Leaders of opposition parties in national politics. The news actors present in the event have discrete role in the nationalism debate, certainly divergent in their ideology (Van Dijk, 1998). Throughout the period of one month, JNU's political position (Martelli, 2016) was presented as a rebellious institution exploiting the state facilities and producing anti-national ideology amongst students. As a national institute of higher education and academic excellence, JNU administration believes in dialogue and discussion (Kumar, 2016b) instead of hooliganism, strikes or violence. In such environment, political intolerance for a scholar's 
view was not being accepted. Of the other issues under debate, unprecedented judicial killing of Parliament attack convict Afzal Guru (George, 2016a) and death of HCU Dalit student Rohith Vemula were questioned by the protesting students. JNUSU students, especially JNUSU president declared an open debate under the ideology of party present in Union ministry. Hence, the Union ministers claimed JNUSU president's speech as 'anti-national' and anticipated it as threat to national integrity (George, 2016a). On the corollary the debate on Newspaper was transformed into a place to blame people.

The videos and discourse broadcasted by the media invoked an omnipresent nationalism debate in media and academia (Aavedna, 2016). In the initial phase, controversies were stirred by the politicians but gradually there was significant comments and support from Professors of national (TNN, 2016d; Pandit, 2016; TNN, 2016e; TNN, 2016f; TOI, 2016b; TNN, 2016g; Gohain, 2016b) and international Universities (TNN, 2016h; TOI, 2016c; TOI, 2016d).

Followed by the arrest of JNUSU president, TOI reported MLAs and lawyers threat towards JNU students and president (Rodrigues, 2016). The recurrent interest shown by media to sustain the debate in a particular University event led to publicity for all the commentators and all kind of aligned views were highlighted by media. Without the trial of court and judiciary, JNUSU students were compelled to be socially ostracised and victimised (Scholars at Risk, 2016) for 'being anti-national'. Unnecessary publicity to each and every speaker superficially raised number of news actors clouding the primary concern of the debate. Students arrested under sedition charges were found not guilty by the court and the videos responsible for the whole debate was proved to be forged (Rani, 2016). Prior to the judicial actions, the actors portrayed in the period of said one month were not quoted in further TOI reporting. Also there were least follow up reports regarding the event, 2016 JNU protest and nationalism debate generated by the event. 


\section{The Nationalism-Patriotism Debate}

Nationality, as a group invokes two parallel concept of nationalism and patriotism, which differ in terms of comprehension and application. Nationalism is composed of national pride and superiority, the events portrayed in any national news reinforce and strengthen that feeling $(\mathrm{Li}$, 2009). On the contrary patriotism is a personal and internalised affection and love towards the nation. Individuals nurturing patriotism tend to be more sacrificing towards the nation than those high on nationalism parameter (Druckman, 1994). 2016 JNU protest invoked nationalism debate in print, broadcast and social media adding views of different stake holders. In print media scholars and politicians discussed various issues, but only to the theoretical premise. Mere brainstorming the idea of nation and nationalism could not be envisaged as promoting patriotism among citizens.

Texts and art have been a source of formation and enhancement of national attachment since the ancient era, including patriotic movies and nationalist literature. Newspapers are easily accessible source of sharing thoughts between leaders, authority and the readers. Although media is an autonomous organization, news ideologies are influenced by the authority on political and administrative grounds (Van Dijk, 1985). Idea behind presenting $2016 \mathrm{JNU}$ protest was not to add a feasible change in national ideology; rather it was a business and sales strategy, as applicable for other news (Menon Malhan, 2013). Purpose of polarising the news actors was to flare the protest movement from plural perspectives of Government and JNUSU participating students. Crystallising of two groups led to a superficial conflict picture for the entire period of debate.

\section{Conclusion}

News, in all sorts of media, may act as discourse, framing an event to be represented in the public forum. The formation and consumption of news are in a progressive continuum often leading to discord between editor's conception and reader's interpretation of the text. Although the text is considered objective, the news presentation involves ideology and power (Wodak \& Ludwig, 1999). News incorporates text and context duly guided 
by the semantics, textual schema, lexicon and rhetoric (Van Dijk, 1988a). The textual narration of the event and semantics used for presentation of a news story covers the publishers' perspective. In case of news covering conflicts and legal procedures, the text acts as a schematic guideline for the readers. Moreover, directive use of adjectives and metaphors create ambiguity and in some cases lead to formation of prejudged view of the reader. In conflict situations, the 'us versus them' concept is debated until the news text uses decisive verbs in reporting, which in turn polarises the readers and creates either belief or disarray. The sentence structure and grammar used in the text and the specific lexicon used in the headlines present implicit meanings open to subjective explanation (Van Dijk, 1988a).

This paper discusses the way India's largest English newspaper discussed and flared up the event to a national level debate along with its other media equivalents. The reason behind instigation of nationalism debate was the ideological standpoint of the student's demands (Sirnate, 2016). As a reputed English Newspaper in National forum, TOI displayed fair amount of negligence in maintaining balance of neutrality. By and large the nationalism debate was among ideological standpoints rather actors or people. The debate was apparently nationalist versus anti-nationalist in nature, but the question underlying was the process of implementation of education and practice of argumentation.

The judicial strategies applied on JNUSU students was evident for how political power can be handled by the government to clamp down views of dissent that confront majoritarian politics (Manjrekar, 2016). Events at HCU and JNU, as projected by the print media, led to ample amount of brainstorming among university students and teachers to rethink about the arbitrary and taken for granted status of academia in national politics. However, there was no remarkable change in terms of policy implications on the basis of arguments generated during the 2016 JNU event. At stake was the sole idea behind all kind of higher educational institutes which are meant to nurture intelligentsia. As the largest English daily, TOI holds readership among readers across different classes and geographical regions. Applying this argument, it acts as a communication channel between Government and society in terms of presenting news. In such circumstances politically mediated news portrayal and profit laden publicity policies deviates the 
media houses from performing its social responsibility. During the entire one month, parity was lost between the initial issue and final arguments leaving a state of indecisiveness among the readers. Instead of portraying a news report, media houses dramatised the event and actors associated with it only.

\section{References}

2016 JNU Protests (n.d.). In Wikipedia. Retrieved from https://en.wikipedia.org/wiki/2016_JNU_protests

Aavedna (2016, April 15). The JNU row- igniting nationwide debate on nationalism vs. anti-nationalism. Aavedna, 3(2). Retrieved from www.mcolegals.in/aavedna.php

Audit Bureau of Circulation (2016). Highest Circulated amongst ABC Member Publications (across languages). Retrieved from Audit Bureau of Circulation website: www.auditbureau.org

Bhagwat, R. (2016, February 2014). Umar Khalid linked to Naxals? Maha police claim nexus. The Times of India. Retrieved from epaperbeta.timesofindia.com

Bell, A. (1991). The Language of News Media. Oxford: Blackwell.

Bhattacharya, S., \& Shakil, S. (2016, February 18). Cops fail to shield Kumar from blows. The Times of India. Retrieved from www.timesofindia.com

Billig, M. (1991). Ideology and Opinions: Studies in Rhetorical Psychology. London: Sage.

Boyd-Barrett, O. (1994). Language and media: a question of convergence. In D. Graddol \& O. Boyd-Barrett (Eds.), Media Texts: Authors and Readers (pp. 22-39). Clevendon: Multilingual Matters Ltd.

Chakravatry, P.K. (2016, February 15). JNUSU president Kanhaiya Kumar's remand extended by two days. Bangla. Retrieved from ebangla.in

Chatterjee, M. (2016, February 16). Budget session likely to feel heat of campus fire. The Times of India. Retrieved from www.timesofindia.com 
Chaudhuri, M. (2010). Indian media and its transformed public. Contributions to Indian Sociology, 44(1\&2), 57-78. doi: 10.1177/006996671004400204

Chomsky, N., \& Herman, E.S. (1988). Manufacturing Consent: The Political Economy of the Mass Media. New York: Pantheon.

Condor, S. (2000). Pride and Prejudice: identity management in English people's talk about 'this country'. Discourse \& Society, 11(2), 175205. doi: 10.1177/0957926500011002003

Condor, S., Tileaga, C., \& Billig, M. (2013). Political Rhetoric. In L. Huddy, D.O. Sears \& J.S. Levy (Eds.), Oxford Handbook of Political Psychology (pp. 262-300). Oxford: Oxford University Press.

Desai, S. (2016, February 22). An Angry Nationalism. The Times of India. Retrieved from www.timesofindia.com

Druckman, D. (1994). Nationalism, Patriotism, and Group Loyalty: A Social Psychological Perspective. Mershon International Studies Review, 38(1), 43-68. doi:10.2307/222610

Fairclough, N. (1992). Discourse and Social Change. Cambridge, MA: Blackwell.

Garg, A. (2016, March 1). 'Tell-tale' Kanhaiya video blurs: Police Say No Electronic Evidence, Only Witness Versions. The Times of India. Retrieved from www.timesofindia.com

Garg, A., \& Shakil, S. (2016, February 18). Kanhaiya was shaking like a coward, won't forget. The Times of India. Retrieved from timesofindia.indiatimes.com

George, G.M. (2016a, February 20). Rohith Vemula to Kanhaiya Kumar: It's Not Over Yet. Countercurrents.org. Retrieved from www.countercurrents.org

George, G.M. (2016b, February 20). Rise of a New Radical Dalit Discourse: Rohith, Kanhaiya \& more... People's Voice. Retrieved from peoplesvoice.in

Gohain, M.P. (Netas of all hues wade in; make JNU theatre of national politics). (2016, February 14). Netas of all hues wade in; make JNU theatre of national politics. The Times of India. Retrieved from www.timesofindia.com 
270 Ray \& Singh - Discourse Analysis on Nationalism in India

Gohain, M.P. (2016b, February 28). JNU must fight for nation, says historian. The Times of India. Retrieved from timesofindia.indiatimes.com

Gohain, M.P. (2016c, February 14). Afzal Guru event row: JNU bars Kanhaiya, 7 others from classes. The Times of India. Retrieved from timesofindia.indiatimes.com

Gohain, M.P. (2016d, February 24). Umar \& Anirban surrender, cops take them on $10 \mathrm{~km}$ midnight ride. The Times of India. Retrieved from epaperbeta.timesofindia.com

Jha, R. (2016). JNU students' union president arrested for sedition, cops search hostels. The Times of India. Retrieved from timesofindia.indiatimes.com

Kohli-Khandekar, V. (2010). The Indian Media Business. New Delhi: SAGE Publications.

Kumar, K. (2016a). We are against institutional violence (Full text of Kanhiya Kumar's JNU speech). Economic and Political Weekly Report, 51(7). Retrieved from www.epw.in

Kumar, M.J. (2016b, May 4). An appeal to JNU student community (university circular). Retrieved from Jawaharlal Nehru University website: www.jnu.ac.in

Li, J. (2009). Intertextuality and national identity: discourse of national conflicts in daily newspapers in the United States and China. Discourse \& Society, 20(1), 85-121. doi: 10.1177/0957926508097096

Manjrekar, N. (2016). Editorial. Contemporary Education Dialogue, 13(2), 167-170. doi: 10.1177/0973184916640401

Martelli, J.T., \& Rahman, S. (2016, March 15). Republic of JNU. Tehelka. Retrieved from www.tehelka.com

Martelli, J.T. (2016). "Sadhus in a Secular Uniform": Indian Marxism and the Practice of Declassing in an Elite Campus. NORIA draft article.

Menon Malhan, S.P. (2013). The TOI story. India: HarperCollins.

Mooney, A., \& Besty, E. (2015). Language, Society \& Power: An Introduction. New York: Routledge.

Pajunen, J. (2008). Linguistic analysis of newspaper discourse I theory and practice. Masters dissertation, University of Tampere. 
Pandit, A. (2016, February 21). 'Diversity key to national unity'. The Times Group E-Paper. Retrieved from epaperbeta.timesofindia.com

Press Council of India (2010). Norms of Journalistic Conduct. Retrieved from the Press Council of India website: www.presscouncil.nic.in

Press Trust of India (2016a, February 12). Anti-India acts won't be tolerated: Rajnath Singh on JNU row. The Economic Times. Retrieved from economictimes.indiatimes.com

Press Trust of India (2016b, February 12). Nation will not tolerate insult to mother India: Smriti Irani. The Economic Times. Retrieved from economictimes.indiatimes.com

Rani, P. (2016, March 2). Kanhaiya Kumar versus State Of NCT Of Delhi. W.P.(Crl) 558/2016 \& Crl.M.A. Nos.3237/2016 \& 3262/2016.

Retrieved from Ikanoon website: indiankanoon.org

Rodrigues, S. (2016). Our Universities are a Space of Debate "AntiNationalism" is a means of suppressing dissent. RGICS Policy Watch, 4(25).

Roy Choudhary, S., \& Grover, S. (2016, February 19). New era for student politics. The Times of India. Retrieved from www.timesofindia.com

Scholars at Risk (Threats to Peaceful Student Expression) (2016). Free to

Think: Report of the Scholars at Risk. Retrieved from Scholars at

Risk Network website: www.scholarsatrisk.org

Sirnate, V. (2016). JNU Arrest: Not Just a Crackdown, It's a War on Democracy. Retrieved from The Hindu Centre for Politics and Public Policy website: www.thehinducentre.com

TNN (2016a, February 10). JNU pulls plug on event against 'judicial killing'. The Times of India. Retrieved from www.timesofindia.com

TNN (Irani invokes 'Mother India', seeks report). (2016b, February 13). Irani invokes 'Mother India', seeks report. The Times of India. Retrieved from www.timesofindia.com

TNN (2016c, February 17). JNU turmoil: Raids on to nab prime suspects.

The Times of India. Retrieved from www.timesofindia.com

TNN (2016d, February 18). Academics unhappy with VC. The Times Group E-Paper. Retrieved from epaperbeta.timesofindia.com

TNN (2016e, February 21). DU meet to show solidarity with JNU. The Times of India. Retrieved from timesofindia.indiatimes.com 
272 Ray \& Singh - Discourse Analysis on Nationalism in India

TNN (2016f, February 24). IIT-M profs divided on JNU. The Navbhvarat Times. Retrieved from navbharattimes.indiatimes.com

TNN (2016g, February 27). Democracy rests on free speech: DU ex-prof. The Times of India. Retrieved from timesofindia.indiatimes.com

TNN (2016h, February 18). Chomsky, Pamuk see Emergency in JNU row.

The Times of India. Retrieved from timesofindia.indiatimes.com

TNN (2016i, February 21). Umar's journo friend quizzed for 2nd time. The

Times of India. Retrieved from epaperbeta.timesofindia.com

TNN (2016j, March 2). Umar, Anirban sent to 14-day judicial custody. The

Times of India. Retrieved from timesofindia.indiatimes.com

TNN (2016k, March 10). Complaint filed against Kanhaiya, JNU professor.

The Times of India. Retrieved from timesofindia.indiatimes.com

TOI (2016a, February 12). Afzal event: Sedition case filed. NYOOOZ.

Retrieved from www.nyoooz.com

TOI (2016b, February 25). 'What must be avoided at all costs is the criminalisation of dissent'. The Times of India. Retrieved from timesofindia.indiatimes.com

TOI (2016c, February 22). JNU echoes at Yale, California. The Times of India. Retrieved from timesofindia.indiatimes.com

TOI (2016d, February 22). Why were cops let in: Chomsky. The Times of India. Retrieved from timesofindia.indiatimes.com

Van Dijk, T.A. (1980a). Macrostructures: An interdisciplinary study of global structures in discourse, interaction, and cognition. Hilisdale, Ni: Lawrence Erlbaum Associates.

Van Dijk, T. A. (1980b). Discourse studies and education. Australian Review of Applied Linguistic, 3(1), pp. 1-28. doi: 10.1075/aral.3.1.01van

Van Dijk, T.A. (1983). Discourse Analysis: Its Development and Application to the structure of news. Journal of Communication. 33(2). 20-43. doi: 10.1111/j.1460-2466.1983.tb02386.x

Van Dijk, T.A. (1985). Introduction: Discourse Analysis in (Mass) Communication Research. In T. A. Van Dijk (Ed.), Discourse and Communication. Berlin: Walter de Gruyter.

Van Dijk, T.A. (1988a). News analysis. Hillsdale, New Jersey: Lawrence Erlbaum. 
Van Dijk, T.A. (1988b). News as Discourse. New Jersey: Lawrence Erlbaum.

Van Dijk, T.A. (1990). Social Cognition and Discourse. In H. Giles \& W.P. Robinson (Eds.), Handbook of Language and Social Psychology. New York: Wiley.

Van Dijk, T.A. (1998). Ideology: A Multidisciplinary Approach. London: Sage.

Van Dijk, T.A., \& Kintsch, W. (1983). Strategies of discourse comprehension. New York: Academic Press.

Van Leeuwen, T. (1996). The representation of social actors. In CaldasCoulthard \& Coulthard (Eds.), Texts and practices: Reading in critical discourse analysis. London: Routledge.

Varshney, A. (1993). India's National Identity, Hindu Nationalism, and the Politics of Anxiety. Daedalus, 122(3), 227-261.

Wodak, R., \& Ludwig, C. (Eds.) (1999). Challenges in a changing world: Issues in Critical Discourse Analysis. Vienna: Passagenverlag.

Wodak, R., \& Meyer, M. (2009). Critical Discourse Analysis: history, agenda, theory, and methodology. In R. Wodak \& M. Meyer (Eds.), Methods of Critical Discourse Analysis. London: Sage.

Wodak, R. (1989). Language, Power and Ideology. Amsterdam: Benjamins. 
274 Ray \& Singh - Discourse Analysis on Nationalism in India

Appendix 1: The series of major highlights following the event are briefly tabulated below

\begin{tabular}{|l|l|}
\hline Date & Post-event highlights \\
\hline February $09^{\text {th }} 2016$ & The event followed by slogan shouting \\
\hline February $10^{\text {th }} 2016$ & $\begin{array}{l}\text { Media started reporting the event followed by } \\
\text { allegation of uttering anti-national slogans }\end{array}$ \\
\hline February $12^{\text {th }} 2016$ & $\begin{array}{l}\text { JNUSU president was arrested and his associates went } \\
\text { into hiding }\end{array}$ \\
\hline February $15^{\text {th }} 2016$ & $\begin{array}{l}\text { JNUSU president and journalists faced violence by the } \\
\text { lawyers at Patiala court Delhi }\end{array}$ \\
\hline February $16^{\text {th }} 2016$ & JNUSU president was sent to 14-day police custody \\
\hline February $17^{\text {th }} 2016$ & $\begin{array}{l}\text { Three ABVP members left official positions protesting } \\
\text { the labeling of JNU as an anti-national institution. }\end{array}$ \\
\hline February $18^{\text {th }} 2016$ & $\begin{array}{l}\text { Intelligence Bureau reported that no evidence was } \\
\text { found against JNUSU president in JNU campus }\end{array}$ \\
\hline February $21^{\text {st }} 2016$ & $\begin{array}{l}\text { Students associated in the event reappeared in front of } \\
\text { media }\end{array}$ \\
\hline February $22^{\text {nd }} 2016$ & $\begin{array}{l}\text { Lawyers confessed intent of violence against JNUSU } \\
\text { president }\end{array}$ \\
\hline February $27^{\text {th }} 2016$ & $\begin{array}{l}\text { The case was transferred to special cell for further } \\
\text { investigation }\end{array}$ \\
\hline March $2^{\text {nd }} 2016$ & $\begin{array}{l}\text { Forensic report proved the videos presented as } \\
\text { evidence against the convicts were forged. }\end{array}$ \\
\hline March $3^{\text {rd }} 2016$ & $\begin{array}{l}\text { JNUSU president was released from the jail } \\
\text { Delhi government filed case against 3 TV channels } \\
\text { over JNU issue }\end{array}$ \\
\hline March $7^{\text {th } 2016}$ &
\end{tabular}


Appendix 2: News Reporting In Feb-March on 2016 JNU Protest: The one month chart of Times of India (Delhi/NCR circulation)

\begin{tabular}{|c|c|c|c|c|c|}
\hline \multicolumn{2}{|l|}{ Initial } & \multicolumn{2}{|l|}{ Mid } & \multicolumn{2}{|l|}{ Residual } \\
\hline Date & $\begin{array}{l}\text { No. Of } \\
\text { article }\end{array}$ & Date & $\begin{array}{l}\text { No. Of } \\
\text { article }\end{array}$ & Date & $\begin{array}{l}\text { No. Of } \\
\text { article }\end{array}$ \\
\hline $10 \mathrm{Feb} 16$ & 01 & $20 \mathrm{Feb} 16$ & 13 & 01 Mar 16 & 03 \\
\hline 11 Feb 16 & 01 & $21 \mathrm{Feb} 16$ & 12 & 02 Mar 16 & 08 \\
\hline $12 \mathrm{Feb} 16$ & 01 & $22 \mathrm{Feb} 16$ & 11 & 03 Mar 16 & 08 \\
\hline $13 \mathrm{Feb} 16$ & 09 & $23 \mathrm{Feb} 16$ & 12 & 04 Mar 16 & 10 \\
\hline $14 \mathrm{Feb} 16$ & 10 & $24 \mathrm{Feb} 16$ & 24 & 05 Mar 16 & 05 \\
\hline $15 \mathrm{Feb} 16$ & 08 & $25 \mathrm{Feb} 16$ & 17 & 06 Mar 16 & 06 \\
\hline 16 Feb 16 & 18 & $26 \mathrm{Feb} 16$ & 17 & 07 Mar 16 & 05 \\
\hline $17 \mathrm{Feb} 16$ & 25 & $27 \mathrm{Feb} 16$ & 05 & 08 Mar 16 & 05 \\
\hline $18 \mathrm{Feb} 16$ & 29 & $28 \mathrm{Feb} 16$ & 12 & 09 Mar 16 & 03 \\
\hline $19 \mathrm{Feb} 16$ & 18 & $29 \mathrm{Feb} 16$ & 11 & 10 Mar 16 & 03 \\
\hline Total & 120 & Total & 134 & Total & 56 \\
\hline
\end{tabular}

Appendix 3: Selected News article Headlines from Times of India (Delhi/NCR circulation) for discourse analysis

\begin{tabular}{|c|c|}
\hline 10 February 2016 & JNU pulls plug on event against 'judicial killing' \\
\hline 11 February 2016 & JNU to probe event to mark Afzal death \\
\hline 12 February 2016 & Afzal event: Sedition case filed \\
\hline 13 February 2016 & $\begin{array}{l}\text { JNU students' union prez arrested for sedition: cops search } \\
\text { hostels }\end{array}$ \\
\hline 14 Febr & $\begin{array}{l}\text { netas of all hues wade in, made JNU theatre of national } \\
\text { politics }\end{array}$ \\
\hline 15 February 2016 & Afzal Guru event at JNU backed by LeT: Rajnath \\
\hline 16 February 2016 & $\begin{array}{l}\text { JNU students, journalists thrashed by lawyers in court as } \\
\text { cops look on: BJP MLA Sharma Seen Beating CPI Activist }\end{array}$ \\
\hline 17 February 2016 & MLA sticks to his guns on shooting 'anti-nationals' \\
\hline 18 February 2016 & Cops Give Goons A Free Hand, Again \\
\hline 19 February 2016 & $\begin{array}{l}\text { Kanhaiya bypasses trial court \& HC, goes straight to SC for } \\
\text { bail citing threat to life }\end{array}$ \\
\hline 20 February 2016 & $\begin{array}{l}\text { JNUSU President's Lawyers To File Writ Under } \\
\text { Constitution To Argue Violation Of Fundamental Rights }\end{array}$ \\
\hline
\end{tabular}


276 Ray \& Singh - Discourse Analysis on Nationalism in India

\begin{tabular}{|c|c|}
\hline 21 February 2016 & $\begin{array}{l}\text { 'Diversity key to national unity': JNU Prof G Arunima } \\
\text { Says Attempt To Impose Homogeneity Is Dangerous }\end{array}$ \\
\hline 22 February 2016 & $\begin{array}{l}\text { All } 5 \text { wanted students back on JNU campus, likely to be } \\
\text { arrested }\end{array}$ \\
\hline 23 February 2016 & $\begin{array}{l}\text { JNU standoff: Students won't surrender, cops bide time } \\
\text { before arresting }\end{array}$ \\
\hline 24 February 2016 & Govt won't back down on JNU, ready for showdown \\
\hline 25 February 2016 & $\begin{array}{l}\text { Govt stands its ground on JNU, Rohith: After Oppn } \\
\text { Charges It With Crushing Dissent, Smriti Counter-Attacks } \\
\text { With Nationalist Pitch }\end{array}$ \\
\hline 26 February 2016 & Police story: Videos just a part of proof \\
\hline 27 February 2016 & Lawyers get SC notice for thrashing Kanhaiya \\
\hline 28 February 2016 & Kanhaiya video nails Bassi claim on attack \\
\hline 29 February 2016 & JNU community debates future course \\
\hline 01 March 2016 & 'Tell-tale' Kanhaiya video blurs \\
\hline 02 March 2016 & Umar, Anirban sent to 14-day judicial custody \\
\hline 03 March 2016 & $\begin{array}{l}\text { Kanhaiya gets 6-month bail with a warning: Stay Away } \\
\text { From Anti-National Activities: HC }\end{array}$ \\
\hline 04 March 2016 & Want freedom in India, not from India: Kanhaiya \\
\hline 05 March 2016 & $\begin{array}{l}\text { My icon is Rohith Vemula, not Afzal Guru: Kanhaiya- } \\
\text { 'JNU Certainly Not Home Of Anti-Nationals' }\end{array}$ \\
\hline 06 March 2016 & $\begin{array}{l}\text { Cops to track Kanhaiya to keep him safe: Ask JNU To Tell } \\
\text { Them About His Movements }\end{array}$ \\
\hline 07 March 2016 & $\begin{array}{l}\text { AMID NATIONALISM DEBATE, POLICE PROPOSAL } \\
\text { DOESN'T CLICK WITH STUDENTS: Cameras on } \\
\text { campus to keep track of outsiders? }\end{array}$ \\
\hline 08 March 2016 & Voice from Valley leads JNU narrative \\
\hline 09 March 2016 & The other face of JNU story \\
\hline 10 March 2016 & JNUSU greets registrar with boycott \\
\hline
\end{tabular}

Appendix 4: Example of derivation of macrostructure from news article (JNU pulls plug on event against 'judicial killing', Times of India, 2016, February 10)

- The news text

JNU pulls plug on event against 'judicial killing 
Once again, a "cultural programme" planned at Jawaharlal Nehru University to protest against the "judicial killing" of Afzal Guru has been scuttled by the administration.

The JNU division of Akhil Bharatiya Vidyarthi Parishad had written to various members of the administration against it and messaged students to protest against the "anti-national" event.

The organizers - a handful of students - say the administration had granted permission "in writing" and then withdrew it "verbally." A photography and a painting exhibition had been planned as part of the programme. "They're not allowing us.

A large number of guards arrived and started removing the photographs. This is not just about Guru but about Kashmir," says Umar Khalid, one of the organisers, adding, "It's like the administration and ABVP are working together. It's the same as what happened in Hyderabad." Apparently, scuttling such tributes is pretty routine.

Khalid says the administration had pulled the plug on a similar event planned last year, also at the "last moment." ABVP's member in the JNU Students' Union, Saurabh Kumar Sharma, had called for a protest. "Some students [are] organising [a] cultural evening to commemorate terrorist Afjal Guru (sic). Please gather at $24 * 7$ (an eatery) to protest [against] this anti-national event. Shaheedo ka apmaan nahi sahega Hindustan," says his message to fellow students.

The dean, students' welfare, S K Goswami explained the withdrawal of permission saying the students "obtained permission by making an incomplete statement." "They said it was just a cultural event and did not give us any details. That's why we have withdrawn permission".

- The first level of Macrostructure

1. Cultural programme was organised at JNU to protest against judicial killing of Afzal Guru

2. JNU administration cancelled the programme

3. JNU division of ABVP complained against the cultural programme to the administration and termed as 'anti-national

4. Few students were in the organising committee who reported that the permission was granted in written form but cancelled verbally 
5. Photography and painting were part of the exhibition under cultural programme

6. Umar Khalid, one of the organisers anticipated ABVP and JNU administration to be associated. He addressed the event to be for Kashmir and also related ruining of the event to student protest of Hyderabad Central University (HCU)

7. Khalid also added cancellation of such event last year

8. ABVP member of JNUSU called for students to protest against such event

9. JNU administration clarified that due to lack of information about the cultural programme, the event permission was cancelled

- The second level of Macrostructure

1. A group of few students organise cultural programme in JNU for protesting against judicial killing of Afzal Guru and supporting Kashmir issue

2. ABVP, a comprising party of JNUSU is against such protest event and tag the students organising as 'anti-national'

3. JNU administration reports lack of information about the nature of event

- The third level of Macrostructure- the Schematic Superstructure

1. The cultural programme organised by some JNU students was opposed by students' wing of the university only; the event was not associated with the university and its administration.

Appendix 5: Example of derivation of microstructure from news article (Cops Give Goons a Free Hand, Again. Times of India, 2016, February 18)

- The news text

\section{Cops Give Goons a Free Hand, Again}

House Courts complex - equidistant from the police headquarters and (the seat of the Union government $)^{4}$ - saw an unprecedented breakdown of law and order, for the second time in three days, on Wednesday. Unbelievably, the goons in black robes who had terrorised reporters and others on Monday, returned for a repeat amidst heavy police presence. Waving the tricolour and shouting slogans, they ran berserk, thrashing reporters, clashing with other lawyers and, finally, assaulting

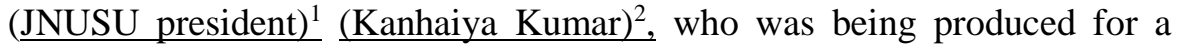


hearing on the sedition charges against him. No action was taken against the lawyers, who had a free run of the place, though the policemen did sporadically intervene to escort people out. Late at night, amidst widespread outrage and condemnation, Delhi Police registered an FIR under sections of assault on the basis of a statement by Kanhaiya which he recorded in the presence of the judge. Police sources said he has identified one of the attackers in the statement. The police are likely to register a second FIR taking suo motu cognisance of the ruckus created by the lawyers through the day. Kanhaiya was brought to court around $2.40 \mathrm{pm}$ through Gate No. 4. While he was being escorted to the court room, 80100 lawyers surrounded the accompanying policemen and rained blows and punches on him. The policemen managed to push back a few of them but were overpowered. However, more cops arrived and managed to rescue him. Some lawyers tried to attack Kumar outside the court as well but the police stopped them. One of them, Surinder Tyagi, later bragged, "We have done our job for today, slapped him... He had to be taught a lesson." Others were heard saying they could "finish" the job if arrested and sent to Tihar.

\begin{tabular}{|c|c|c|c|c|c|}
\hline Actors & $\begin{array}{l}\text { JNU } \\
\text { administr } \\
\text { ation }\end{array}$ & $\begin{array}{l}\text { JNUSU } \\
\text { students } \\
\text { involved in } \\
\text { the protest }\end{array}$ & $\begin{array}{l}\text { ABVP } \\
\text { students } \\
\text { opposing the } \\
\text { event }\end{array}$ & $\begin{array}{l}\text { ministers } \\
\text { involved } \\
\text { in debate }\end{array}$ & $\begin{array}{l}\text { leaders of } \\
\text { opposition } \\
\text { parties at } \\
\text { center }\end{array}$ \\
\hline $\begin{array}{l}\text { Micros } \\
\text { tructur } \\
\mathrm{e}\end{array}$ & $\begin{array}{l}\text { Backgro } \\
\text { unding }^{1}\end{array}$ & Presence $^{2}$ & Absence $^{3}$ & $\begin{array}{l}\text { Suppressi } \\
\text { on }^{4}\end{array}$ & Absence $^{5}$ \\
\hline
\end{tabular}


280 Ray \& Singh - Discourse Analysis on Nationalism in India

Appendix 6: Poster of the main event of 2016 JNU protest (Retrieved from www.thequint_2016-02_f5d0a984-87e1-4fca-9584-1353d2caa459_Afzak Event.jpg)

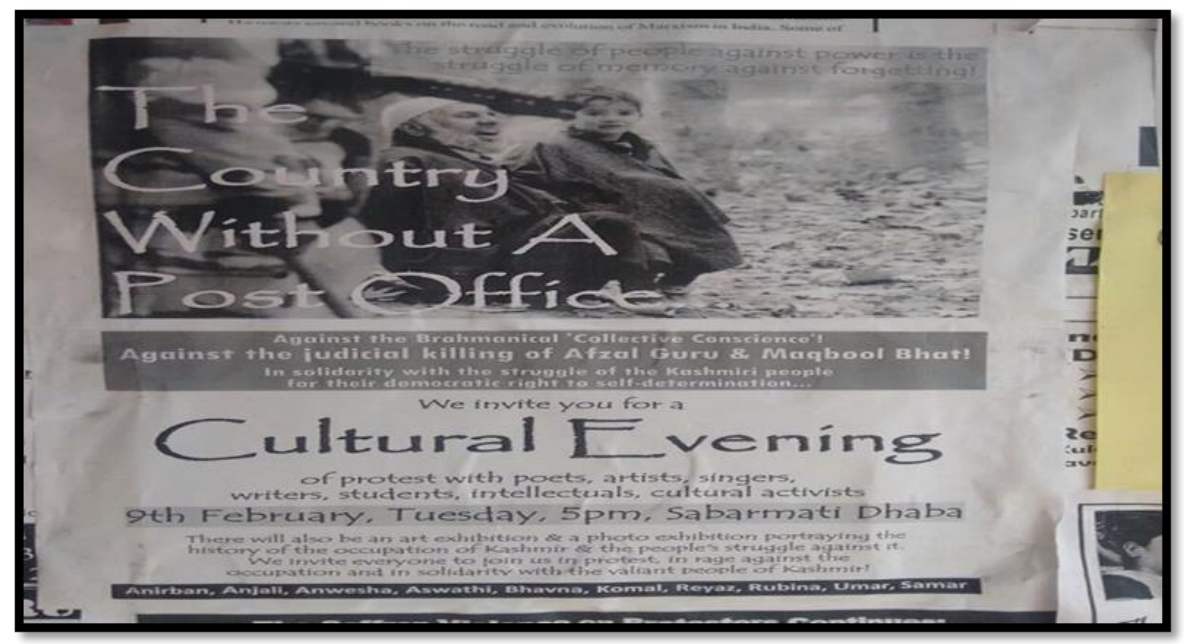

Shovana Ray is PhD student at the Defence Institute of Psychological Research, India

Jitendra Kumar Singh is a scientist at the Defence Institute of Psychological Research, India

Contact Address: Shovana Ray, Defence Institute of Psychological 